\title{
ЭКОЛОГИЧЕСКИЕ ПРОБЛЕМЫ ПОЙМЕННЫХ ОЗЕР ПО РЕЗУЛЬТАТАМ ИССЛЕДОВАНИЯ БАССЕЙНОВ РЕК СУРА И ХОПЕР В ПЕНЗЕНСКОЙ ОБЛАСТИ
}

\author{
Е.А. Дудкин ${ }^{1 *}$, А.И. Иванов ${ }^{2}$, В.Ю. Ильин ${ }^{1}$ \\ ${ }^{1}$ Пензенский государственный университет; \\ ${ }^{2}$ Пензенская государственная сельскохозяйственная академия (Пенза, Россия) \\ * Эл.noчma: myrow@yandex.ru \\ Статья поступила в редакичи 30.09.2014; принята к печати 12.12.2014
}

Проблемы состояния экосистем пойменных озер исследованы авторами в бассейнах рек Сура и Хопер в Пензенской области (западная часть Приволжской возвышенности в 600 км к юго-востоку от Москвы). Установлено, что при увеличении степени зарастания водоемов изменяется соотношение экологических групп водных растений. При степени зарастании менее $20 \%$ площади водного зеркала участие гидатофитов в видовом составе максимальное - до 25\%. При увеличении степени зарастания их доля снижается. На последних стадиях зарастания, когда оно достигает 95-100\%, доминирующее положение занимают аэрогидатофиты, негативно влияющие на световой и тепловой режимы водоема в целом. При зарастании снижается рН, содержание фосфатов, ионов кальция и магния, увеличивается содержание ионов железа и органического вещества. Вода приобретает токсические свойства, что подтверждается ее биотестированием, и откладывает отпечаток на ихтиофауну. Из комплекса речных видов рыб полностью исчезают реофильные представители, доминирующее положение приобретают инвазивные виды - карась белый и головешка-ротан. Снижение поемности и аллювиальности не только ускоряет процесс зарастания старичных водоемов. Если в прошлом на смену превратившимся в травяные болота старицам появлялись новые, формировавшиеся в результате меандрирования русла, то в настоящее время этот процесс приостановился. Все это дает основания предполагать, что возросшая скорость деградации экосистем озер-стариц приведет в ближайшие $30-50$ лет к их исчезновению на изученной территории.

Ключевые слова: пойменные озера, водная растительность, гидрохимические показатели, биотестирование, ихтиофауна.

\section{ECOLOGICAL PROBLEMS OF FLOODPLAIN LAKES EVIDENT FROM STUDIES OF SURA AND KHOPER RIVER BASINS$$
\text { IN PENZA REGION, RUSSIA }
$$$$
\text { Ye.A. Dudkin }{ }^{1 *} \text {, A.I. Ivanov }{ }^{2} \text {, V.Yu. Ilyin }{ }^{1}
$$ \\ ${ }^{1}$ Penza University and ${ }^{2}$ Penza Agricultural Academy (Penza, Russia)

$$
\text { *E-mail:myrow@yandex.ru }
$$

Problems in floodplain lakes ecological conditions were assesses in Sura and Khoper river basins of Penza Region (the western part of Volga Upland, $600 \mathrm{~km}$ southest of Moscow). Increasing overgrowing of water pools was found to be associated with changes in the proportions of ecological groups of aquatic plants. Upon overgrowing within $\mathbf{2 0} \%$ of water area, the proportion of hydatophytes is maximal, up to $25 \%$. Their proportion decreases with the further increase in overgrowing, which at its advances stages $(95$ to $100 \%)$ is associated with the predominance of aerohydatophytes, which adversely affect the light and thermal conditions of water. Increasing overgrowing leads to decreases in $\mathrm{pH}$ and phosphate and calcium and magnesium ion levels and to increases in iron ion and organic matter. Water acquires toxic properties confirmed by biotesting and impacting the ichthyofauna. Rheophils disappear and invasive species, such as Prussian carp and Chinese sleeper gain predominance. Decreased alluvial and floodplain processes not only accelerate floodplain lake overgrowing. In the past, lakes transformation into marches was compensated by new lake formation due to stream canal meandering, which is virtually defunct at present. All the above suggests that the increased rate of degradation of floodplain lake ecosystems found within the territory studied is prone with their disappearance in the nearest 30 to 50 years.

Keywords: floodplain lakes, aquatic flora, ichthyofauna, hydrochemical parameters, biotesting.

\section{Введение}

Одним из важнейших условий, определяющих устойчивое состояние биосферы, является сохранение природных экосистем. Среди них особое значение имеют сообщества организмов, свойственные речным поймам. Это связано с тем, что лотические сообщества рек, для которых важен фактор течения, не обеспечивают себя необходимым для питания животных планктоном и детритом. Поэтому биота, свойственная руслу реки, через пищевые цепи оказывается связана с биотой пойменных озер и наземных сообществ. Лишь такая взаимосвязь обеспечивает высокую продуктивность и устойчивость речных экосистем, от состояния которых, в конечном счете, зависит качество воды [5].

Пойменные озера-старицы играют особую роль в жизни речных экосистем. Они представляют собой своеобразные природные отстойники, собирающие поверхностный и внутрипочвенный сток с водоразделов, а также концентрирующие в себе основную массу родниковой воды. При условии ненарушенности экосистем старичных водоемов стекающая с водоразделов вода доводится в них до определенных параметров, которые соответствуют речной системе [11].

Проблема деградации пойменных экосистем имеет глобальный характер. В настоящее время она отра- 
жена в работах как отечественных [13-15, 19], так и зарубежных исследователей [22-25]. Эти процессы имеют общие закономерности и связаны как с природными, так и антропогенными факторами.

В последние десятилетия наметилась четкая тенденция в плане деградации экосистем старичных водоемов. В связи с этим целью данной работы была оценка экологической ситуации и состояния биоты пойменных озер бассейнов р. Сура и Хопер в пределах Пензенской области, расположенной в западной части Приволжской возвышенности в 600 км к юговостоку от Москвы. В районе исследований находятся истоки и верховья вышеназванных рек, то есть происходит качественное и количественное формирование стока, в котором существенна роль всех компонентов природных комплексов водосборной площади, в том числе и пойменных озер [6].

Гидрохимические показатели воды и донных отложений этих водоемов до начала наших исследований не определялись, а влияние на них процесса зарастания вообще не изучалось. Кроме того, с учетом динамичности состояния водных экосистем их оценку необходимо регулярно повторять, чтобы объективно оценивать происходящие изменения и делать соответствующие прогнозы.

\section{Объекты и методы}

Для описания водной растительности использованы общепринятые в гидроботанике подходы $[1,8$, 20]. Определение растений осуществлялось в основном по десятому изданию Флоры средней полосы европейской части России [9]. В соответствии с ним приводятся русские и латинские названия видов. Количественный химический анализ проводили методами, допущенными для целей государственного экологического контроля (Природоохранительные нормативные документы, федеральные - ПНД Ф).
Концентрацию фосфатов в природной воде определяли фотометрическим методом (ПНД Ф 14.1:2.112-97); $\mathrm{pH}$ - потенциометрическим методом (ПНД Ф 14.1:2:3:4.121-97); ХПК - титриметрическим методом (ПНД Ф 14.1:2.100-97); железа - фотометрическим методом с сульфосалициловой кислотой (ПНД Ф 14.1:2.50-96); кальция и магния - капиллярным электрофорезом (ПНД Ф 14.1:2:4.167-2000). Методы биотестирования включали оценку токсичности по смертности дафний [3], определение уровня флюоресценции хлорофилла [4] и интенсивности бактериальной биолюминесценции тест-системой «Эколюм» (ПНД Ф 14.1:2:3:4.11-04). Отлов ихтиофауны осуществляли общепринятыми методами [16], таксономическое описание дано по Атласу пресноводных рыб России [17].

\section{Результаты}

В ходе ботанических исследований было выявлено 60 видов растений, вызывающих зарастание пойменных озер. Для изучения ценотической значимости отдельных видов нами использовалась шкала численности Браун-Бланке («-» - вид очень редок с незначительным покрытием; «+»- вид встречается редко, покрытие мало; 1 - число особей велико, но покрытие незначительно или особи разрежены, но покрытие большое; 2 - число особей велико, покрытие от 5 до $25 \% ; 3$ - при любом числе особей покрытие от 25 до 50\%; 4 - при любом числе особей покрытие от 50 до 75\%; 5 - при любом числе особей покрытие больше 75\%) [2].

В табл. 1 представлены результаты исследований по пяти наиболее изученным водоемам, для которых характерна неодинаковая степень зарастания, доминирование различных видов и различное соотношение экологических групп растений, которые даны по И.Г. Серебрякову [21].

Видовой состав растений водоемов района исследований

Табл. 1

\begin{tabular}{|c|c|c|c|c|c|}
\hline \multirow[b]{2}{*}{ Экологические группы и виды растений } & \multicolumn{5}{|c|}{$\begin{array}{l}\text { Обилие видов растений } \\
\text { в изучаемых водоемах }\end{array}$} \\
\hline & 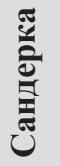 & 胥 & 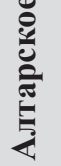 & $\begin{array}{l}\stackrel{8}{E} \\
\stackrel{0}{0}\end{array}$ & है \\
\hline \multicolumn{6}{|l|}{ Гидатофиты (12) } \\
\hline Наяда большая (Najas major All.) & & + & & & \\
\hline Пузырчатка обыкновенная (Utricularia vulgaris L.) & 1 & & & & \\
\hline Рдест Берхтольда (Potamogeton berchtoldii Fieb.) & - & & & & \\
\hline Рдест блестящий (Potamogeton lucens L.) & 2 & 1 & + & & \\
\hline Рдест волосовидный (Potamogeton trichoides Cham. et Schlecht.) & 1 & 1 & + & & \\
\hline Рдест гребенчатый (Potamogeton pectinatus L.) & 1 & & & & \\
\hline Рдест пронзеннолистный (Potamogeton perfoliatus L.) & 2 & 2 & & & \\
\hline Рдест Фриза (Potamogeton friesii Rupr.) & - & & & & \\
\hline Роголистник погруженный (Ceratophyllum demersum L.) & 2 & 1 & & & \\
\hline Роголистник полупогруженный (Ceratophyllum submersum L.) & 2 & 1 & & & \\
\hline Уруть мутовчатая (Myriophyllum verticillatum L.) & 1 & 1 & & & \\
\hline Элодея канадская (Elodea canadensis Michx.) & 1 & + & & & \\
\hline
\end{tabular}




\begin{tabular}{|c|c|c|c|c|c|}
\hline Аэрогидатофиты (13) & & & & & \\
\hline Водокрас лягушачий (Hydrocharis morsus-ranae L.) & 2 & 2 & 1 & + & + \\
\hline Горец земноводный (Polygonum amphibium L.) & + & + & & & \\
\hline Кубышка желтая (Nuphar lutea (L.) Smith) & 2 & 2 & 1 & + & \\
\hline Кувшинка чисто-белая (Nymphaea candida J. et C. Presl) & 2 & 2 & & & \\
\hline Многокоренник обыкновенный (Spirodela polyrrhiza (L.) Scleid.) & 1 & 1 & 2 & 1 & 2 \\
\hline Рогульник плавающий (Trapa natans L.) & & + & & & \\
\hline Ряска горбатая (Lenma gibba L.) & 1 & 1 & 2 & 1 & 2 \\
\hline Ряска малая (Lenma minor L. s. 1.) & + & + & 3 & 1 & 5 \\
\hline Ряска трехдольная (Lenma trisulca L.) & 1 & 1 & 2 & 1 & 2 \\
\hline Сабельник болотный (Comarum palustre L.) & & + & + & 1 & \\
\hline Сальвиния плавающая (Salvinia natans (L.) All.) & + & 2 & & & \\
\hline Стрелолист обыкновенный (Sagittaria sagittifolia L.) & + & 2 & + & - & \\
\hline Телорез алоэвидный (Stratiotes aloides L.) & + & 1 & 3 & 5 & + \\
\hline Гидрофиты (23) & & & & & \\
\hline Белокрыльник болотный (Calla palustris L.) & & + & & & \\
\hline Вероника поручейная (Veronica beccabunga L.) & - & + & & & \\
\hline Вех ядовитый (Cicuta virosa L.) & 1 & 1 & 2 & 3 & 1 \\
\hline Ежеголовник простой (Sparganium simplex auct. non Huds.) & 2 & 2 & 1 & + & \\
\hline Жерушник земноводный (Rorippa amphibia (L.) Bess.) & - & & & & \\
\hline Ирис ложноаировый (Iris pseudoacorus L.) & + & + & 1 & & \\
\hline Камыш озерный (Scirpus lacustris L.) & 2 & & & & \\
\hline Кипрей болотный (Epilobium palustre L.) & + & + & + & + & - \\
\hline Кипрей волосистый (Epilobium hirsutum L.) & + & 1 & + & + & \\
\hline Манник большой (Glyceria maxima (Hartm.) Holmb.) & 2 & 2 & 2 & 3 & 1 \\
\hline Манник плавающий (Glyceria fluitans (L.) R. Br.) & 1 & 1 & 1 & & \\
\hline Омежник водный (Oenanthe aquatica (L.) Poir.) & + & - & & & \\
\hline Осока береговая (Carex riparia Curt.) & 1 & 1 & 2 & 2 & 1 \\
\hline Осока вздутая (Carex rostrata Stokes) & 1 & + & & & \\
\hline Осока заостренная (Carex acutiformis Ehrh.) & 1 & + & + & + & \\
\hline Осока ложносытевая (Carex pseudocyperus L.) & & 1 & & & \\
\hline Осока омская (Carex omskiana Meinsh.) & & + & & & \\
\hline Осока острая (Carex acuta L.) & - & + & + & & \\
\hline Паслен сладко-горький (Solanum dulcamara L.) & + & 1 & + & - & + \\
\hline Рогоз широколистный (Typha latifolia L.) & 1 & + & + & + & \\
\hline Рогоз узколистный (Typha angustifolia L.) & 2 & + & & & \\
\hline Тростник обыкновенный (Phragmites australis (Cav.) Trin. ex Steud.) & 2 & 1 & + & 3 & - \\
\hline Частуха подорожниковая (Alisma plantago-aquatica L.) & 1 & 1 & + & + & - \\
\hline Гигрофиты (12) & & & & & \\
\hline Вербейник обыкновенный (Lysimachia vulgaris L.) & & + & & & \\
\hline Вербейник монетчатый (Lysimachia nummularia L.) & & + & & & \\
\hline Девясил высокий (Inula helenium L.) & & + & & & \\
\hline Зюзник высокий (Lycopus exaltatus L. fil.) & & + & & & \\
\hline Ива пепельная (Salix cinerea L.) & + & + & 1 & 2 & 1 \\
\hline Камыш лесной (Scirpus sylvaticus L.) & 1 & 1 & 2 & 2 & 1 \\
\hline Лютик ползучий (Ranunculus repens L.) & & - & & & \\
\hline Мята перечная (Mentha piperita L.) & & + & & & \\
\hline Повой заборный (Calystegia sepium (L.) R.Br.) & + & + & + & + & + \\
\hline Посконник коноплевидный (Eupatorium cannabinum L.) & & - & & & \\
\hline Чистец болотный (Stachys palustris L.) & + & + & 1 & 1 & + \\
\hline Шлемник обыкновенный (Scutellaria galericulata L.) & + & + & + & + & + \\
\hline Всего видов & 47 & 54 & 30 & 25 & 18 \\
\hline
\end{tabular}


Озеро Сандерка находится на первых стадиях зарастания. Степень зарастания водного зеркала не превышает 20\%. В нем выявлено 47 видов растений, из которых 23,4\% составляют гидатофиты.

Для Старой Суры характерна средняя степень зарастания, которая в разных частях русла составляет от 20 до 50\% (в среднем 30\%). Этому водоему свойственно максимальное видовое разнообразие - 54 вида. Гидатофиты представлены восемью видами, на них приходится 14,8\%. То есть на средней стадии зарастания видовое разнообразие достигает максимума, но роль гидатофитов снижается.

В озере Алтарском, зарастание которого составляет на разных участках русла от 50 до $80 \%$ (в среднем $70 \%$ ), наблюдается рост значимости аэрогидатофитов. При этом на участках русла, затененных лесной растительностью, доминирует ряска малая, а на открытых, хорошо освещаемых участках доминирует телорез алоэвидный. Видовой состав растений становится беднее. В этом водоеме выявлено всего 30 видов растений. Гидатофиты представлены всего двумя видами и составляют $6,6 \%$.

Озера Долгое и Свинуха характеризуются максимальной степенью зарастания. Водная растительность здесь покрывает 95-100\% поверхности акватории. В оз. Долгом, берега которого не покрыты лесом, при хорошей освещенности монодоминантом оказывается телорез алоэвидный. Видовой состав растений сокращается до 25 видов, группа гидатофитов полностью выпадает.

Оз. Свинуха расположено внутри лесного массива, в результате чего его поверхность постоянно находится в условиях затенения. Водная растительность покрывает 98\% акватории. Однако доминантом здесь оказывается ряска малая, которой сопутствует ряска горбатая и трехбороздчатая. Видовой состав растений становится еще беднее и сокращается до 18 видов, группа гидатофитов полностью выпадает.

Описанные закономерности проявляются не только в водоемах, указанных в табл. 1. Они характерны для пойменных озер района исследований в целом. Как показывает анализ данных табл. 2, для всех изученных водоемов, находящихся на первой стадии зарастания и характеризующихся зарастанием менее $20 \%$ акватории, характерно наибольшее участие видов гидатофитов.
В группе озер, находящих на средней стадии зарастания, количество видов увеличивается, но доля гидатофитов в видовом составе существенно снижается. Дальнейшее зарастание ведет к снижению общего количества видов, сокращению числа видов гидатофитов и в итоге к их полному исчезновению. Численность отдельных видов аэрогидатофитов, напротив, сильно возрастает.

Зарастание телорезом ведет к очень серьезным изменениям биоты озер. Это связано в первую очередь с тем, что на участках водного зеркала, покрытых этим растением, полностью меняются световой и тепловой режимы. Телорез препятствует проникновению света в толщу воды и ее прогреванию. В результате исчезают гидатофиты и фитопланктон. Есть основания предполагать, что телорез обладает неблагоприятными аллелопатическими свойствами. Соседства с ним не выдерживает большинство водных и околоводных растений. Водокрас лягушачий, кубышка желтая, многокоренник обыкновенный и сальвиния плавающая уживаются с ним, хотя и снижают свою численность (табл. 1). Ежеголовник простой, стрелолист обыкновенный, частуха подорожниковая резко снижают свою численность, а такие виды аэрогидатофитов, как кувшинка чисто-белая и рогульник плавающий, полностью исчезают.

Процесс деградации биоты озер усугубляется тем, что телорез дает ежегодно колоссальную биомассу до 4,8 кг на 1 м² [12], которая практически не утилизируется консументами. Это значит, что на 1 га заросшего телорезом озера поступает ежегодно 48 т органики. Ее разложение подо льдом ведет к резкому снижению содержания кислорода в воде и выделению сероводорода, что губительно сказывается на всей зообиоте, и в первую очередь на ихтиофауне.

Зарастание ряской также меняет световой и тепловой режимы озер. Однако в отличие от телореза она поедается животными, в первую очередь водоплавающими птицами. Поэтому в таких озерах органогенный ил накапливается менее интенсивно, и соответственно сохраняется более благоприятный кислородный режим.

Увеличение степени зарастания существенно влияет на гидрохимические показатели (табл. 3). Значительно возрастает показатель химического поглощения кислорода (ХПК), особенно подо льдом в зимний

Количество видов и доля гидатофитов в водоемах, характеризующихся различной степенью зарастания

\begin{tabular}{|c|c|c|c|}
\hline Название озера & Степень зарастания, \% & Число видов растений & $\begin{array}{l}\text { Доля гидатофитов } \\
\text { в видовом составе, \% }\end{array}$ \\
\hline Зубриловское & $<20$ & 32 & 42,3 \\
\hline Сандерка & $<20$ & 47 & 23,4 \\
\hline \multicolumn{3}{|c|}{ Средний \% гидатофитов в видовом составе } & 32,8 \\
\hline Старая Сура & 30 & 54 & 14,8 \\
\hline Чапчор & 50 & 45 & 21,1 \\
\hline \multicolumn{3}{|c|}{ Средний \% гидатофитов в видовом составе } & 17,9 \\
\hline Алтарское & 70 & 30 & 6,6 \\
\hline Барское & 60 & 32 & 9,1 \\
\hline \multicolumn{3}{|c|}{ Средний \% гидатофитов в видовом составе } & 7,8 \\
\hline Долгое & 98 & 25 & 0 \\
\hline Свинуха & 98 & 18 & 0 \\
\hline \multicolumn{3}{|c|}{ Средний \% гидатофитов в видовом составе } & 0 \\
\hline
\end{tabular}


Химический состав воды старичных водоемов различной степени зарастания

\begin{tabular}{|c|c|c|c|c|c|c|}
\hline Озеро & pH & $\begin{array}{c}\text { ХПК (зимой), } \\
\text { мгО } / \text { л }\end{array}$ & $\begin{array}{l}\mathrm{Ca}^{2+}, \\
\text { мг/л }\end{array}$ & $\begin{array}{l}\mathrm{Mg}^{2+}, \\
\text { мг/л }\end{array}$ & 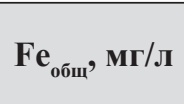 & $\begin{array}{c}\text { Фосфат-ион, } \\
\text { мг/л }\end{array}$ \\
\hline Зубриловское & $7,52 \pm 0,04$ & $30,4 \pm 0,8$ & $74,7 \pm 1,8$ & $16,7 \pm 0,7$ & $0,30 \pm 0,04$ & $0,72 \pm 0,08$ \\
\hline Сандерка & $7,38 \pm 0,03$ & $26,1 \pm 0,8$ & $60,2 \pm 1,3$ & $10,3 \pm 0,8$ & $0,40 \pm 0,05$ & $0,41 \pm 0,04$ \\
\hline Старая Сура & $6,92 \pm 0,03$ & $37,3 \pm 1,2$ & $30,2 \pm 1,3$ & $5,8 \pm 0,6$ & $0,30 \pm 0,06$ & $0,28 \pm 0,03$ \\
\hline Чапчор & $6,81 \pm 0,03$ & $38,3 \pm 1,2$ & $48,4 \pm 1,8$ & $8,8 \pm 0,8$ & $0,60 \pm 0,06$ & $0,25 \pm 0,03$ \\
\hline Алтарское & $6,57 \pm 0,04$ & $51,4 \pm 1,9$ & $26,9 \pm 0,9$ & $5,5 \pm 0,8$ & $0,80 \pm 0,06$ & $0,21 \pm 0,05$ \\
\hline Барское & $6,59 \pm 0,04$ & $54,2 \pm 2,1$ & $22,8 \pm 0,8$ & $7,6 \pm 0,7$ & $0,60 \pm 0,05$ & $0,82 \pm 0,06$ \\
\hline Долгое & $6,68 \pm 0,04$ & $53,3 \pm 1,4$ & $25,9 \pm 1,2$ & $4,1 \pm 0,8$ & $0,80 \pm 0,05$ & $0,28 \pm 0,06$ \\
\hline Свинуха & $7,04 \pm 0,03$ & $59,2 \pm 2,3$ & $20,2 \pm 0,9$ & $4,2 \pm 0,6$ & $1,10 \pm 0,08$ & $0,90 \pm 0,06$ \\
\hline
\end{tabular}

Табл. 4

Результаты биотестирования воды старичных водоемов различной степени зарастания

\begin{tabular}{|l|c|c|c|}
\hline \multirow{2}{*}{ Озеро } & \multicolumn{3}{|c|}{ Острая токсичность } \\
\cline { 2 - 4 } & $\begin{array}{c}\text { По тест-объекту } \\
\text { Daphnia magna }\end{array}$ & $\begin{array}{c}\text { По тест-объекту Scenedesmus } \\
\text { quadricauda }\end{array}$ & $\begin{array}{c}\text { По тест-объекту } \\
\text { «Эколюм» }\end{array}$ \\
\hline Зубриловское & Нет & Нет & Нет \\
\hline Сандерка & Нет & Нет & Нет \\
\hline Старая Сура & Нет & Образец токсичен & Есть \\
\hline Чапчор & Нет & Образец токсичен & Есть \\
\hline Алтарское & Нет & Образец токсичен & Есть \\
\hline Барское & Нет & Образец токсичен & Есть \\
\hline Долгое & Нет & Образец сильно токсичен & Есть \\
\hline Свинуха & Есть & Образец сильно токсичен & \\
\hline
\end{tabular}

период; снижается рН и содержание ионов кальция и магния; количество общего железа, напротив, увеличивается. Также снижается количество фосфатов (по фосфат-иону), однако в некоторых водоемах с рясковым типом зарастания наблюдается их повышенная концентрация. Все это приводит к существенному ухудшению качества среды обитания водных организмов, что наглядно подтверждается результатами биотестирования (табл. 4).

Процесс зарастания пойменных озер в последние десятилетия резко ускорился (табл. 5). Как показывает сравнение полученных нами результатов с данными Ивушкина А.С. [7], с 1993 по 2014 г. степень зарастания большинства изученных водоемов существенно возросла.

Изменение степени зарастания водоемов с 1993 по 2014 г.

\begin{tabular}{|l|c|c|}
\hline \multirow{2}{*}{\multicolumn{1}{|c|}{ Озеро }} & \multicolumn{2}{|c|}{ Степень зарастания (\%) } \\
\cline { 2 - 3 } & $\mathbf{1 9 9 3} \mathbf{~} \mathbf{.}$ & $\mathbf{2 0 1 4} \mathbf{~} \mathbf{.}$ \\
\hline Зубриловское & 15 & $<20$ \\
\hline Сандерка & 20 & $<20$ \\
\hline Старая Сура & 20 & 30 \\
\hline Чапчор & 15 & 50 \\
\hline Алтарское & 20 & 70 \\
\hline Барское & 20 & 60 \\
\hline Долгое & 35 & 98 \\
\hline Свинуха & 35 & 98 \\
\hline
\end{tabular}

\section{Обсуждение}

Околоводная и водная растительность, свойственная озерам-старицам, не представляет собой климак- совое сообщество. В этих водоемах идет первичная сукцессия, завершающаяся превращением озера в осоковое болото [10]. Однако скорость этой сукцессии может идти разными темпами в зависимости от степени антропогенного влияния и ряда процессов глобального характера. Так, например, ряд озерных водоемов в пойме р. Суры, в частности оз. Чапчор и Шевокал, имеют давнюю историю, что подтверждается мордовским происхождением их названий (Чапчор - багор, Шевокал - чаша с рыбой), хотя мордовское население было вытеснено в правобережье p. Суры еще в XVIII в. Под этими названиями они фигурируют и на топографической карте съемки А.И. Менде (1863-1866 гг.). Несмотря на значительный возраст этих водоемов, их экосистемы до 70-х гг. $\mathrm{XX}$ в. были относительно ненарушенными. Степень зарастания водного зеркала не превышала 20\%. В оз. Чапчор существовала популяция рогульника плавающего, озеро изобиловало рыбой [5]. За последние 40 лет степень зарастания озера приблизилась к 50\%, сократились численность и видовое разнообразие рыб. Описанная ситуация характерна не только для названных озер. Она типична для пойм изученных рек в целом.

Ускорение процесса деградации пойменных озер связано с рядом причин природного и антропогенного характера. В первую очередь это глобальное потепление климата, в результате которого зимы стали мягче и, соответственно, ослабилось промерзание почвы. В результате этого полые воды впитываются более активно, разливы ослабились, и лед с вмерзшими в него растительными остатками перестал выноситься из озер, что ускорило накопление илов органического происхождения. 
Среди антропогенных факторов в первую очередь следует указать на строительство дамб и земляных плотин, перегораживающих протоки, соединяющие старицы с основным руслом реки. Полное прекращение стока, или провод его через трубы нарушает процесс водообмена с основным руслом и миграцию водных организмов.

Кроме того, большой вред нанесло проведение в поймах мелиоративных осушительных работ и строительство гидротехнических сооружений. В частно- сти, постройка на р. Сура плотины Сурского гидроузла привела к утрате ряда крупных озерных водоемов, затопленных водохранилищем. Ниже г. Пензы, в связи с тем что сток был зарегулирован плотиной, ослабился весенний подъем воды.

Интересно, что негативное воздействие оказало и ослабление некоторых видов антропогенной нагрузки. Прекращение выпаса скота привело к разрастанию по берегам водоемов ивы пепельной, в результате чего существенно увеличился приток листового

\section{Видовой состав рыбообразных и рыб в бассейнах р. Сура и Хопер на территории Пензенской области}

\begin{tabular}{|c|c|c|c|}
\hline Вид & $\underset{0}{\stackrel{5}{0}}$ & 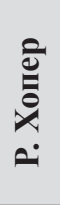 & 兽 \\
\hline Минога украинская Eudontomyzon mariae (Berg, 1931) & + & + & - \\
\hline Стерлядь Acipenser ruthenus (Linnaeus, 1758) & + & - & - \\
\hline Щука Esox lucius (Linnaeus, 1758) & + & + & + \\
\hline Лещ Abramis brama (Linnaeus, 1758) & + & + & - \\
\hline Белоглазка Abramis sapa (Pallas, 1814) & + & + & - \\
\hline Быстрянка Alburnoides bipunctatus (Bloch, 1782) & + & - & - \\
\hline Уклейка Alburnus alburnus (Linnaeus 1758) & + & + & + \\
\hline Жерех обыкновенный Aspius aspius (Linnaeus, 1758) & + & + & - \\
\hline Густера Blicca bjorkna (Linnaeus, 1758) & + & + & - \\
\hline Карась золотой Carassius carassius (Linnaeus, 1758) & + & + & + \\
\hline Подуст волжский Chondrostoma variabile (Jakowlew, 1870) & + & + & - \\
\hline Сазан обыкновенный, карп Cyprius carpio (Linnaeus, 1759) & + & + & - \\
\hline Пескарь Gobio gobio (Linnaeus, 1758) & + & + & - \\
\hline Верховка Leucaspius delineatus (Heckel, 1843) & + & + & + \\
\hline Голавль Leuciscus cephalus (Linnaeus, 1758) & + & + & - \\
\hline Елец Данилевского Leuciscus danilewskii (Kessler, 1877) & - & + & - \\
\hline Язь Leuciscus idus (Linnaeus, 1758) & + & + & - \\
\hline Елец Leuciscus leuciscus (Linnaeus, 1758) & + & + & - \\
\hline Чехонь Pelecus cultratus (Linnaeus, 1758) & + & + & - \\
\hline Гольян обыкновенный Phoxinus phoxinus (Linnaeus, 1758) & + & - & - \\
\hline Горчак Rhodeus sericeus (Pallas, 1776) & + & + & + \\
\hline Пескарь белоперый Romanogobio albipinnatus (Lukasch, 1933) & + & - & - \\
\hline Плотва Rutilus rutilus (Linnaeus, 1758) & + & + & + \\
\hline Красноперка Scardinius erythrophthalmus (Linnaeus, 1758) & + & + & + \\
\hline Линь Tinca tinca (Linnaeus, 1758) & + & + & + \\
\hline Рыбец Vimba vimba (Linnaeus, 1758) & - & + & - \\
\hline Голец усатый Barbatula barbatula (Linnaeus, 1758) & + & + & - \\
\hline Щиповка сибирская Cobitis melanoleuca (Nichols, 1925) & + & + & - \\
\hline Щиповка обыкновенная Cobitis taenia (Linnaeus, 1758) & + & + & - \\
\hline Щиповка южнорусская Cobitis rossomeridianalis (Vasiljeva et Vasiljev, 1998) & - & + & - \\
\hline Вьюн Misgurnus fossilis (Linnaeus, 1758) & + & + & + \\
\hline Сом обыкновенный Silurus glanis (Linnaeus, 1758) & + & + & - \\
\hline Налим Lota lota (Linnaeus, 1758) & + & + & - \\
\hline Ерш обыкновенный Gymnocephalus cernuus (Linnaeus, 1758) & + & + & - \\
\hline Ерш донской Gymnосеphalus acerinus (Guldenstadt, 1775) & - & + & - \\
\hline Окунь речной Perca fluviatilis (Linnaeus, 1758) & + & + & + \\
\hline Судак обыкновенный Stizostedion lucioperca (Linnaeus, 1758) & + & + & - \\
\hline Подкаменщик обыкновенный Cottus gobio Linnaeus, 1758 & + & - & - \\
\hline Всего видов & 34 & 33 & 10 \\
\hline
\end{tabular}


опада. Вторым фактором было запрещение сетевого лова рыбы бреднями, в процессе которого удалялась биомасса водных растений.

Примером тому служат проведённые в последние 10-15 лет наблюдения за состоянием ихтиофауны на 20 озерах-старицах, в том числе рассмотренных выше (табл. 6).

Кроме перечисленных в таблице аборигенных видов рыбообразных и рыб в рассматриваемых речных системах, в качестве незначительной примеси встречаются нижеследующие интродуценты: в p. Сура - черноморская игла Syngnathus nigrolineatus (Eichwald, 1831), белый Hypophthalmichthys molitrix (Valenciennes, 1844) и пестрый Aristichthys nobilis (Richardson, 1846) толстолобики, амур белый Ctenopharyngodon idella (Valenciennes, 1844). Появление большинства из этих рыб (за исключением первого вида) связано с зарыблением прудов на притоках реки. Исключение составляют карась белый Carassius auratus (Linnaeus, 1758) и головешка-ротан Perccotus glenii (Dybowski, 1877). Первый заселил как русла р. Сура и Хопер, так и их старичные водоемы. Второй вид в этих речных системах отмечен только в озерах-старицах.

Из комплекса речных видов рыб в пойменных озеpax полностью исчезли реофильные представители, например, голавль, язь, два вида ельцов, гольян речной и др. Среди причин этого явления в первую очередь следует указать на ослабление весенних паводков и прекращение связи озер с реками из-за постройки гидротехнических сооружений. На примере соседней Мордовии это также подтверждается [18].

Сведения о состоянии ихтиофауны озер-стариц в других смежных регионах нам не известны, несмотря на многочисленные публикации, отражающие рыбопродуктивность промысловых видов рыб, обитающих в руслах рек и их притоках.

В ходе проведенных нами исследований было установлено, что в последние десятилетия процесс зарастания озер-стариц резко ускорился, что подтверждается работами других исследователей в бассейнах не только Суры [14] и Хопра [15], но и иных рек [13, 19]. Этот процесс ведет к деградации всей озерной экосистемы. Снижение поемности и аллювиальности связываются главным образом с антропогенным воздействием [19], но по нашему мнению существенную роль здесь играет и глобальное потепление климата. Ситуация усугубляется тем, что, если в прошлом на смену превратившимся в травяные болота старицам появлялись новые, формировавшиеся в результате меандрирования русла, то в настоящее время такой процесс приостановился. Это дает основания предполагать, что экосистемы озер-стариц в ближайшие 30-50 лет полностью исчезнут на изученной территории.

\section{Литература}

1. Белавская А.П. К методике изучения водной растительности // Первая Всесоюзная конференция по высшим водным и прибрежноводным растениям. Тезисы докладов. - Борок, 1977. - C. 42-44.

2. Вальтер Г. Общая геоботаника: Пер. с нем. / Перев. и предисл. А.Г. Еленевского. - М. : Мир, 1982. - 264 с.

3. Жмур Н.С. Методика определения токсичности воды и водных вытяжек из почв, осадков сточных вод, отходов по смертности и изменению плодовитости дафний. - 2-е изд., испр. и доп. - М. : АКВАРОС, 2007. - 52 с.

4. Жмур Н.С. Методика определения токсичности вод, водных вытяжек из почв, осадков сточных вод и отходов по изменению уровня флуоресценции хлорофилла и численности клеток водорослей. - 2-е изд., испр. и доп. M. : АКВАРОС, 2007. - 48 c.

5. Зайдфудим П.Х. Стратегия и механизмы инновационного развития долины реки Суры (конвергентное проектирование): Т. I «Мониторинг экологической ситуации в бассейне реки Суры в пределах Пензенской области» / П.Х. Зайдфудим, А.И. Иванов, В.Н. Чупис. Москва-Торопец : РИТА, 2011. - 180 с.

6. Иванов А.И. Мониторинг состояния пойменных озер бассейна реки Суры в Пензенской области // Эколого-экономические и социальные проблемы развития регионов России. Сборник научных трудов РАЕН / Ред: А.И. Иванов, Ю.А. Мазей, Т.Г. Стойко. - М. : ГОУ ВПО МГУЛ, 2007. - С. 163-172.
7. Ивушкин А.С. Водорегулирующие сооружения Пензенской области / А.С. Ивушкин, И.М. Крышов, К.К. Кантеев. - Пенза, 1993. $268 \mathrm{c}$.

8. Лепилова Т.К. Инструкция для исследования высшей водной растительности // Инструкция по биол. исследованиям вод / Ред.: К.М. Дерюгин. - Л. : Изд-во Гос. гидрол. ин-та, 1934. - Ч. 1. - Раздел А. - Вып. 5. - 48 с.

9. Маевский П.Ф. Флора средней полосы европейской части России. - 10-е изд. - М. : Товарищество научных изданий КМК, 2006. - 600 с.

10. Миркин Б.М. Закономерности развития растительности речных пойм. - М. : Наука, 1974. - 174 c.

11. Небел Б. Наука об окружающей среде: Как устроен мир: В 2 т. / Пер. с англ. М.В. Зубкова и др. - М. : Мир, 1993. - 420 с.

12. Папченков В.Г. Растительный покров водоемов и водотоков Среднего Поволжья. Ярославль : ЦМП МУБиНТ, 2001. - 214 с.

13. Папченков В.Г. Закономерности зарастания водотоков и водоемов // Экология. - 2003. № 1. - C. $18-22$.

14. Петрова E.A. Особенности зарастания озер-стариц реки Суры // Вестник Чувашского государственного педагогического университета им. И.Я. Яковлева. - 2009. - № 3-4. C. $77-83$.

15. Печенюк E.B. Динамика зарастания пойменных озер в Хоперском государственном заповеднике // Ботан. журн. - 1986. - Т. 71. C. 637-642. 
16. Правдин И.Ф. Руководство по изучению рыб (преимущественно пресноводных). 4-е изд. - М. : Пищевая промышленность, 1966. -226 с.

17. Решетников Ю.С. Атлас пресноводных рыб России: В 2 т. / Ред.: Ю.С. Решетников. М. : Наука, 2002. - 632 с.

18. Ручин А.Б., Вечканов В.С., Кузнечов В.А., Ильин В.Ю., Добролюбов А.Н., Осипов В.В., Клевакин А.А., Семенов Д.Ю. История ихтиологических исследований в бассейне реки Суры // Известия Самарского научного центра Российской академии наук. Общие проблемы экологии. - 2009. - Т. 11. - № 1. - С. 7-21.

19. Сапаев В.И. Проблемы сохранения экосистем поймы Амура при создании сети ГЭС // Экологические проблемы бассейнов крупных рек: Тез. межд. конф. - Тольятти, 1998. - С. 31-32.

20. Садчиков А.П., Кудряшов М.А. Гидроботаника: Прибрежно-водная растительность. М. : ИЦ «Академия», 2005. - 240 с.
21. Серебряков И.Г. Экологическая морфология растений. - М. : Высшая школа, 1962. $378 \mathrm{c}$.

22. Gallardo B., Cabezas A., Gonzalez E., Comin F.A. Effectiveness of a newly created oxbow lake to mitigate habitat loss and increase biodiversity in a regulated floodplain // Restoration Ecology. - 2012. - Vol. 20. - P. 387-394.

23. Glinska-Lewczuk K. Water quality dynamics of oxbow lakes in young glacial landscape of NE Poland in relation to their hydrological connectivity // Ecological Engineering. - 2009. - 35. P. 25-37.

24. Lawniczak A.E. Overgrowing of two polymictic lakes in Central-Western Poland // Limnological Review. - 2010. - Vol. 10. - P. 147-156.

25. Van Geest G.J., Wolters H., Roozen F.C.J.M., Coops H., Roijackers R.M.M., Buijse A.D., Scheffer $M$. Water-level fluctuations affect macrophyte richness in floodplain lakes // Hydrobiologia. 2005. - Vol. 539. - P. 239-248.

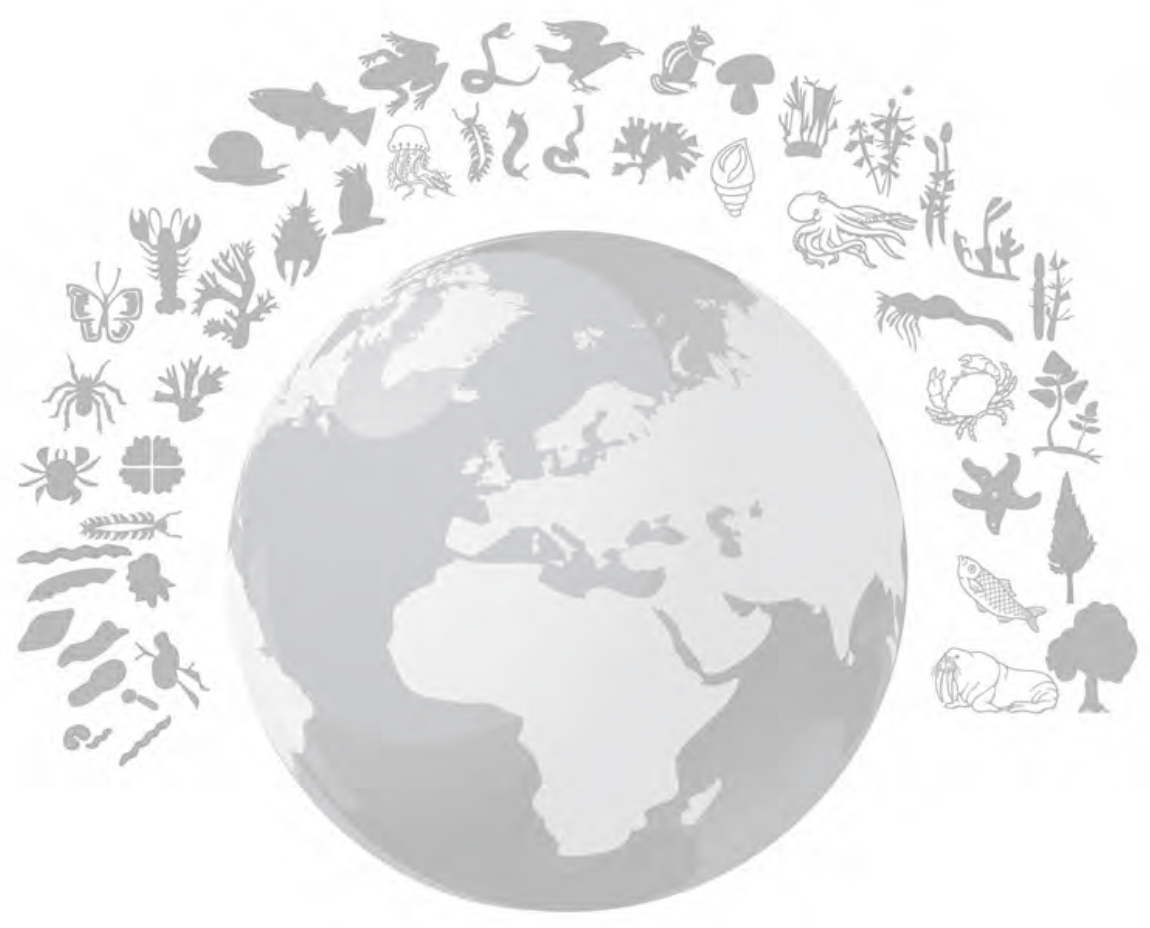

